\title{
Anti-plasmodial activity of Norcaesalpin D and extracts of four medicinal plants used traditionally for treatment of malaria
}

Ramadhani Selemani Omari Nondo ${ }^{1 *}$, Mainen Julius Moshi ${ }^{1}$, Paul Erasto ${ }^{2}$, Pax Jessey Masimba ${ }^{1}$, Francis Machumi ${ }^{3}$, Abdul Waziri Kidukuli ${ }^{3}$, Matthias Heydenreich ${ }^{4}$ and Denis Zofou ${ }^{5}$

\begin{abstract}
Background: Malaria is an old life-threatening parasitic disease that is still affecting many people, mainly children living in sub-Saharan Africa. Availability of effective antimalarial drugs played a significant role in the treatment and control of malaria. However, recent information on the emergence of $P$. falciparum parasites resistant to one of the artemisinin-based combination therapies suggests the need for discovery of new drug molecules. Therefore, this study aimed to evaluate the antiplasmodial activity of extracts, fractions and isolated compound from medicinal plants traditionally used in the treatment of malaria in Tanzania.
\end{abstract}

Methods: Dry powdered plant materials were extracted by cold macerations using different solvents. Norcaesalpin D was isolated by column chromatography from dichloromethane root extract of Caesalpinia bonducella and its structure was assigned based on the spectral data. Crude extracts, fractions and isolated compound were evaluated for antiplasmodial activity against chloroquine-sensitive $P$. falciparum (3D7), chloroquine-resistant $P$. falciparum (Dd2, K1) and artemisinin-resistant P. falciparum (IPC 5202 Battambang, IPC 4912 Mondolkiri) strains using the parasite lactate dehydrogenase assay.

Results: The results indicated that extracts of Erythrina schliebenii, Holarrhena pubescens, Dissotis melleri and C. bonducella exhibited antiplasmodial activity against Dd2 parasites. Ethanolic root extract of E. schliebenii had an $\mathrm{IC}_{50}$ of $1.87 \mu \mathrm{g} / \mathrm{mL}$ while methanolic and ethanolic root extracts of $H$. pubescens exhibited an $I_{50}=2.05 \mu \mathrm{g} / \mathrm{mL}$ and $\mathrm{IC}_{50}=2.43 \mu \mathrm{g} / \mathrm{mL}$, respectively. Fractions from $\mathrm{H}$. pubescens and C. bonducella roots were found to be highly active against K1, Dd2 and artemisinin-resistant parasites. Norcaesalpin D from C. bonducella root extract was active with $I_{50}$ of $0.98,1.85$ and $2.13 \mu \mathrm{g} / \mathrm{mL}$ against 3D7, Dd2 and IPC 4912-Mondolkiri parasites, respectively.

Conclusions: Antiplasmodial activity of norcaesalpin D and extracts of E. schliebenii, H. pubescens, D. melleri and C. bonducella reported in this study requires further attention for the discovery of antimalarial lead compounds for future drug development.

Keywords: Antiplasmodial, norcaesalpin D, E. schliebenii, H. pubescens, D. melleri, C. bonducella

\footnotetext{
* Correspondence: rnondo@muhas.ac.tz; nondo75@yahoo.com

${ }^{1}$ Department of Biological and Pre-Clinical Studies, Institute of Traditional

Medicine, Muhimbili University of Health and Allied Sciences, P.O.Box 65001,

Dar es Salaam, Tanzania

Full list of author information is available at the end of the article
} 


\section{Background}

Malaria is an old mosquito borne disease which is still a public health concern particularly in Africa [1]. Globally, about 214 million people were recorded to suffer from malaria in 2015 of which majority are found in subSaharan Africa [2].

Efforts to control malaria have mainly depended on the availability of effective antimalarial drugs and insecticides to reduce both infections and transmission [3]. Use of insecticide-treated bed nets (INTs), indoor residual spraying (IRs), chemoprophylaxis in pregnant mothers and increased access to effective antimalarial drugs have significantly reduced morbidity and mortality, especially, in malaria endemic areas [4]. However, these achievements are undermined by the existence of malaria parasites and mosquitoes which are resistant to antimalarial drugs and pesticides, respectively [5].

In the early 2000s $P$. falciparum parasites resistant to mefloquine, chloroquine, quinine, proguanil, atovaquone and sulphadoxine-pyrimethamine, but not, artemisinins were reported [6]. The WHO responded by restricting artemisinin monotherapies and recommended use of artemisinin-based combination therapies, ACTs [7] in which the artemisinins are combined with long acting drugs. Subsequently, increased access to the ACTs has contributed significantly to reducing both infections and malaria-related deaths, especially in sub-Saharan Africa where the transmission is high [8]. Despite this positive outcome, a recent report from South East Asia revealed that $P$. falciparum parasites resistant to artemisinin have now been identified in Myanmar, Cambodia, Thailand, Viet Nam and Lao People's Democratic Republic [9]. Recently clinical failure to dihydroartemisinin-piperaquine combination therapy was reported [10], suggesting that the problem is increasing and thus there is need for development of new drugs. To address this challenge, researches which will identify new chemical compounds with antimalarial properties are continuously needed. Studying medicinal plants used in traditional medicine for the treatment of malaria is among the many approaches used to identify new compounds with antimalarial properties [11]. Therefore, this paper reports the antiplasmodial activity of extracts, fractions and one compound from medicinal plants traditionally used for the treatment of malaria in Tanzania.

\section{Methods}

\section{Malaria parasites}

Chloroquine-sensitive $P$. falciparum (3D7), chloroquineresistant $P$. falciparum (Dd2 and $\mathrm{K} 1$ ) and artemisininresistant $P$. falciparum (IPC-5202 Battambang-Cambodia 2011 and IPC-4912 Mondolkiri-Cambodia 2011) strains were used. All parasites were obtained from BEI-resources (MR4/ATCC Manassas, VA, USA).

\section{Chemicals and reagents}

Silica gel (230-400 mesh, $60 \AA$ A; Sigma, Steinheim, Germany), dichloromethane (Carlo erba', Val-de-Reuil, France), ethyl acetate (Carlo erba), ethanol (Carlo erba), methanol (Carlo erba), dimethyl sulfoxide (Carlo erba), thin layer chromatography (TLC) plates $\left(60 \mathrm{~F}_{254}\right.$, Merck, Darmstadt, Germany), Albumax II (GIBCO ${ }^{\mathrm{mm}}$, Invitrogen, USA), RPMI-1640 (Sigma), Foetal Bovine Serum (FBS, BioWhittaker, Verviers, Belgium), were used. All chemicals and other materials used in this study were purchased through local suppliers in Tanzania and in Cameroon, and directly from SIGMA (Sigma', Steinheim, Germany).

\section{Collection and extraction of plant materials}

Previous studies indicate that decoctions of E. schliebenii roots and stem bark, $H$. pubescens roots, C. bonducella roots and leaves, and decoction of $D$. melleri aerial parts are used in traditional medicine for the treatment of malaria [12-14]. Dissotis melleri Hook.f (Melastomataceae, voucher No. RN 55) aerial parts were collected from Buzi Kishura village in Kagera region and Caesalpinia bonducella (L.) Flem (Caesalpiniacea, Voucher no. RN 93) roots were collected from Gezaulole village in Dar es Salaam region, Tanzania. Holarrhena pubescens Huch-Ham (Apocynaceae, voucher No. 4665) roots and Erythrina schliebenii Harms (Fabaceae, voucher No. 4661) stem bark and roots were collected from Mchakama village in Lindi region, Tanzania. The plants were identified by a botanist, Mr. Selemani Haji, and the voucher specimens are deposited in the Herbarium of the Institute of Traditional Medicine, Muhimbili University of Health and Allied Sciences.

Dry powdered plant materials were extracted by cold maceration using 80\% ethanol, methanol, dichloromethane, or water. The crude extracts were dried in vacuo at $50{ }^{\circ} \mathrm{C}$. Aqueous extracts were dried by freeze-drying and the dry extracts were kept at $-20{ }^{\circ} \mathrm{C}$.

\section{Fractionation of root extract of $H$. pubescens}

Methanolic root extract of $H$. pubescens and dichloromethane root extract of $C$. bonducella were selected for fractionation after showing both in vitro antiplasmodial activity reported in this study and in vivo antimalarial activity reported in our previous study [15]. The methanolic root extract of $H$. pubescens was fractionated by column chromatography with silica gel as the stationary phase. The column was eluted by solvents of increasing polarity starting with petroleum ether $(100 \%)$. The polarity of eluting solvent was increased using a step gradient of ethyl acetate in petroleum ether in the following ratios: ethyl acetate/petroleum ether (1:9), ethyl acetate/petroleum ether (1:4), ethyl acetate/petroleum ether (2:3); ethyl acetate/petroleum ether (1:1), ethyl acetate/petroleum ether (7:3); ethyl acetate/petroleum ether (4:1), ethyl acetate $(100 \%)$ and finally eluted with methanol (100\%). After 
analysis by thin layer chromatography (TLC), similar fractions were combined to obtain 11 major fractions coded as methanolic root extract of $H$. pubescens (HPRM-1 to 11). All fractions were air-dried and evaluated for antiplasmodial activity against chloroquine-sensitive $P$. falciparum (3D7), chloroquine-resistant P. falciparum (Dd2 and K1) and artemisinin-resistant P. falciparum (IPC-5202 and IPC-4912) parasites.

\section{Isolation and characterization of pure compound from $C$. bonducella root extract \\ General experimental procedure}

Isolation of the compounds was done by column chromatography with silica gel as the stationary phase and further purified by size exclusion column chromatography using Sephadex LH-20. Separation was monitored by TLC in aluminium plates pre-coated with silica gel and spots were visualized under UV light $(254 \mathrm{~nm})$ and after spraying with vanillin plus heat [16]. ${ }^{1} \mathrm{H},{ }^{13} \mathrm{C}$, COSY, HSQC, HMBC and NOESY spectral data were recorded on a Bruker Avance $(600 \mathrm{MHz})$ NMR spectrometer in $\mathrm{CD}_{2} \mathrm{Cl}_{2}$ solvent with the residual solvent signal ( ${ }^{1} \mathrm{H}$ : $5.31,{ }^{13} \mathrm{C}: 53.7 \mathrm{ppm}$ ) as internal standard. EIMS spectrum was recorded on GC-MS TRACE DSQII single quadruple mass spectrometer.

\section{Extraction, fractionation, isolation and characterization of compound}

The dry-powdered roots of C. bonducella $(1.7 \mathrm{Kg})$ were macerated twice in dichloromethane for $24 \mathrm{~h}$ at room temperature. The extract was dried in vacuo to give $46.3 \mathrm{~g}$, out of which $40 \mathrm{~g}$ were fractionated in silica gel column chromatography and eluted by solvents of increasing polarity starting with $2.5 \mathrm{~L}$ of $100 \%$ petroleum ether (yield $1.7 \mathrm{~g}$ ) followed by $2.0 \mathrm{~L}$ of $1: 1$ petroleum ether/dichloromethane (yield $6.5 \mathrm{~g}$ ), $2.5 \mathrm{~L}$ of $100 \%$ dichloromethane (yield $12.0 \mathrm{~g}$ ), $2.5 \mathrm{~L}$ of $1: 1$ dichlromethane/ethyl acetate (yield $16.7 \mathrm{~g}$ ) and $0.8 \mathrm{~L}$ of $100 \%$ ethyl acetate (yield $1.0 \mathrm{~g}$ ). All fractions were screened for in vivo antimalarial activity against $P$. berghei ANKA parasites at a dose of $200 \mathrm{mg} / \mathrm{kg} /$ day for a total of four daily doses given orally. Among the tested fractions, 1:1 dichloromethane/ethyl acetate fraction showed highest in vivo activity and therefore was selected for further fractionation and isolation of active compounds. About $16.0 \mathrm{~g}$ of 1:1 dichloromethane/ethyl acetate fraction was chromatographed in a silica gel column and eluted by solvents of increasing polarity starting with 1:1 petroleum ether/dichloromethane, then 1:4 petroleum ether/ dichloromethane, 100\% dichloromethane and 9:1 dichloromethane/ethyl acetate. Fraction number 12 obtained from 9:1 dichloromethane/ethyl acetate showed some crystals and this fraction was further purified by sephadex column eluted by $100 \%$ ethyl acetate to produce 12 sub-fractions in which sub-fraction number 3 was found to be white amorphous solid pure compound.

\section{In vitro antiplasmodial activity}

Chloroquine-sensitive $P$. falciparum (3D7), chloroquineresistant $P$. falciparum (Dd2 and K1) and artemisininresistant $P$. falciparum (IPC 5202 Battambang-Cambodia 2011 and IPC 4912 Mondolkiri- Cambodia 2011) strains were cultured in vitro according to the method of Trager and Jensen [17]. Parasites were grown in uninfected $\mathrm{O}^{+}$ human red blood cells as host cells and maintained in RPMI-1640 culture medium supplemented with $\mathrm{NaHCO}_{3}$ (2 $\mathrm{mg} / \mathrm{mL})$, hypoxanthine $(10 \mu \mathrm{g} / \mathrm{mL})$, glucose $(2 \mathrm{mg} / \mathrm{mL})$, albumax II $(1 \%)$ and gentamicin $(10 \mu \mathrm{g} / \mathrm{mL})$. The parasite cultures were incubated at $37{ }^{\circ} \mathrm{C}$ in $5 \% \mathrm{CO}_{2}, 5 \% \mathrm{O}_{2}$ and $90 \% \mathrm{~N}_{2}$. All solutions were filter-sterilized by $0.22 \mu \mathrm{m}$ syringe-adapted filters (Corning , NY, USA).

In vitro antimalarial activity of extracts, fractions and norcaesalpin D isolated from $C$. bonducella roots was assessed by parasite lactate dehydrogenase (pLDH) assay [18]. Non-synchronized 1\% parasitized red blood cells (pRBCs, mostly rings and trophozoites) at 2\% haematocrit (hct) in 96 well microtiter plates (Costar, Corning, NY, USA) were incubated with different concentrations of extract, fractions or norcaesalpin D. Quinine was used as a standard drug. Each concentration was tested in triplicate and each experiment was done twice. Wells with only $1 \%$ pRBCs at $2 \%$ hct without extract, fraction or drug were included as negative controls (100\% parasite growth) while wells with uninfected red blood cells only at $2 \%$ hct served as blank controls. Parasite cultures with extracts, fractions or compound were maintained for $48 \mathrm{~h}$ at $37{ }^{\circ} \mathrm{C}$ in $5 \% \mathrm{CO}_{2}, 5 \% \mathrm{O}_{2}$, and $90 \% \mathrm{~N}_{2}$. After $48 \mathrm{~h}$ of incubation, the plates were frozen overnight at $-20{ }^{\circ} \mathrm{C}$ and antimalarial activity was determined by $\mathrm{pLDH}$ assay performed as described previously [19]. Concentrations inhibiting $50 \%$ of the parasite growth $\left(\mathrm{IC}_{50}\right)$ were determined by HN-NonLin V1.1, 2002 software (http://www.meduniwien.ac.at/user/harald.noedl/malaria/ software.html) (Noedl H, 2002. Armed Forces Research Institute for Medical Sciences, Bangkok, Thailand).

\section{Cytotoxicity}

Cytotoxicity was evaluated on LLC-MK2 monkey kidney epithelial cells. Cells were grown in culture medium prepared from solid RPMI-1640 with L-glutamine and 25 mM HEPES (Sigma', Steinheim, Germany). The medium was supplemented with $\mathrm{NaHCO}_{3}(2 \mathrm{mg} / \mathrm{mL})$, hypoxanthine $(10 \mu \mathrm{g} / \mathrm{mL})$, glucose $(11.1 \mathrm{mM}), 10 \%$ FBS (BioWhittaker, Verviers, Belgium) and gentamicin (5 $\mu \mathrm{g} / \mathrm{mL}$ ). Adherent cells detached by trypsin-EDTA treatment were distributed into 96 well microtiter plates at 10,000 cells in $100 \mu \mathrm{L}$ per well. The cells were incubated for $48 \mathrm{~h}$ to allow them to attach before adding the 
extracts. After $48 \mathrm{~h}$, the medium was removed completely from each well, and $100 \mu \mathrm{L}$ of fresh culture medium was then added. Thereafter, $100 \mu \mathrm{L}$ of crude extracts $(400 \mu \mathrm{g} / \mathrm{mL})$ were added in row $\mathrm{H}$ and then serially diluted two fold to give concentrations ranging from 200 to $3.125 \mu \mathrm{g} / \mathrm{mL}$. Cells in row A served as controls without drug (100\% growth). The cells with or without extracts/fractions/compound were incubated at $37{ }^{\circ} \mathrm{C}$ in atmosphere of $5 \% \mathrm{CO}_{2}$ air for $72 \mathrm{~h}$ before determining their viability. Each concentration was tested in triplicate and each experiment was done twice. Cell viability was determined by MTT assay and cytotoxic activity was determined according to a method used in our previous study [20]. Gleevec (Imatinib) was used as a cytotoxic drug. Selectivity index (SI) corresponding to the ratio between cytotoxic activity and antiplasmodial activity was calculated as follows: $\mathrm{SI}$ (Plasmodium) $=\mathrm{CC}_{50}$ (LLC-MK2)/ $\mathrm{IC}_{50}$ (P. falciparum).

\section{Results}

\section{Structure elucidation of Norcaesalpin D}

Norcaesalpin D (Fig. 1) was isolated as a white amorphous solid pure compound from the dichloromethane root extract of $C$. bonducella. The EI-MS gave molecular ion peak $\left[\mathrm{M}^{+}\right]$at $m / z 346$ consistent with the molecular formula $\mathrm{C}_{20} \mathrm{H}_{26} \mathrm{O}_{5}$. The ${ }^{1} \mathrm{H}-\mathrm{NMR}$ revealed twenty five protons including methyl doublet at $\delta 0.87$, two methyl singlets at $\delta 1.15$ and at $\delta 3.65$ (methoxy protons) together with two olefinic protons of a 2,3-disubstituted furan ring at $\delta 6.59(\mathrm{dd}, \mathrm{J}=2.0,0.4)$ and at $\delta 7.32$ $(\mathrm{d}, \mathrm{J}=1.8)$. The ${ }^{13} \mathrm{C}-\mathrm{NMR}$ showed signals for twenty carbons of which two were carbonyl carbons at $\delta 195.9$ corresponding to $\mathrm{C}-14$ ketone group and at $\delta 177.2$ representing C-19 carbonyl ester. One signal for methoxy carbon at

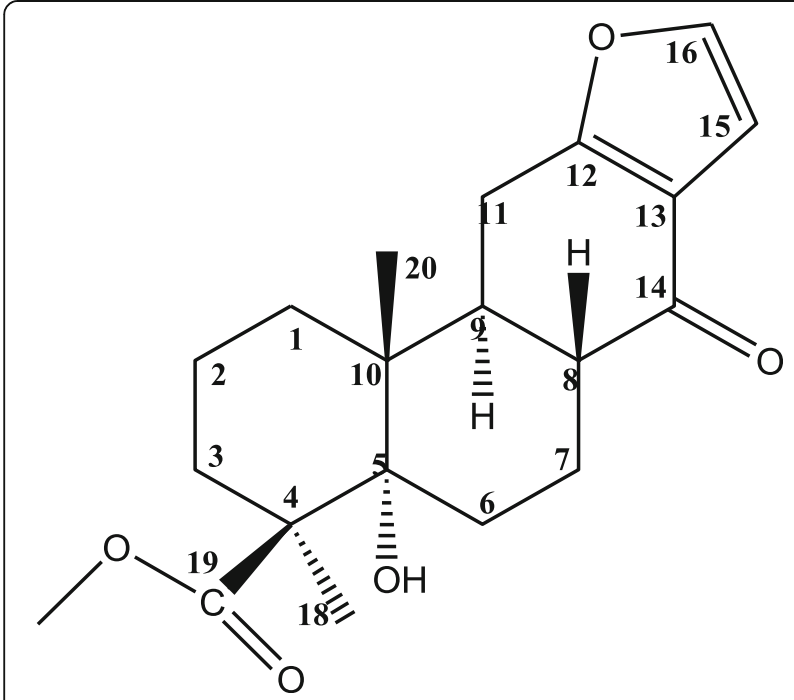

Fig. 1 Structure of Norcaesalpin D (methyl-12,16-epoxy-5ahydroxynorcasa-12,15-dien-14-one-19-carboxylate) $\delta 51.7$ was observed. In addition to that, four signals for olefinic carbons at $\delta 167.1$ (C-12), $\delta 119.8$ (C-13), $\delta 106.4$ $(\mathrm{C}-15)$ and $\delta 143.1$ (C-16) of furan ring attached to another ring were observed. The significantly downfield chemical shift value of $\mathrm{C}-12$ was attributed to resonance of a conjugated carbonyl residue at $\mathrm{C}$-14. Its structure (Fig. 1) was assigned (Table 1) based on ${ }^{1} \mathrm{H},{ }^{13} \mathrm{C}$, COSY, HSQC, HMBC and NOESY spectral data. The compound was identified as norcaesalpin D, previously isolated from the dichloromethane root extract of $C$. bonducella and its structure was confirmed by comparing with previously reported data [21]; however no antiplasmodial activity was reported before.

In vitro antiplasmodial and cytotoxic activity of norcaesalpin D and extracts of four plants

Antiplasmodial activity of extracts of E. schliebenii, $H$. pubescens, D. melleri and C. bonducella was determined

Table $1{ }^{1} \mathrm{H}-\mathrm{NMR}$ and ${ }^{13} \mathrm{C}-\mathrm{NMR}$ ( $\delta$ values; J values in $\mathrm{Hz}$ ) data for Norcaesalpin D

\begin{tabular}{|c|c|c|c|c|}
\hline \multirow[t]{2}{*}{ Position } & \multicolumn{2}{|c|}{$\begin{array}{l}\text { Observed value } \\
\left(600 \mathrm{MHz} \text { in } \mathrm{CD}_{2} \mathrm{Cl}_{2}\right)\end{array}$} & \multicolumn{2}{|c|}{$\begin{array}{l}\text { Reported value by Roach } \\
\text { et al., } 2007(500 \mathrm{MHz} \\
\left.\text { in } \mathrm{CDCl}_{3}\right)\end{array}$} \\
\hline & $\delta_{C}$ mult & $\delta_{\mathrm{H}}$, mult $(J$ in $\mathrm{Hz})$ & $\delta_{C}$ & $\delta_{\mathrm{H}}$, mult $(J$ in $\mathrm{Hz})$ \\
\hline 1 & 32.0 & $\begin{array}{l}1.59, \mathrm{~m} \\
1.39, \mathrm{~m}\end{array}$ & 31.6 & $\begin{array}{l}1.40, \mathrm{~m} \\
1.58, \mathrm{~m}\end{array}$ \\
\hline 2 & 18.9 & $\begin{array}{l}1.59, \mathrm{~m} \\
1.92, \mathrm{~m}\end{array}$ & 18.7 & $\begin{array}{l}1.53, \mathrm{~m} \\
1.86, \mathrm{~m}\end{array}$ \\
\hline 3 & 31.9 & $\begin{array}{l}1.56, \mathrm{~m} \\
1.90, \mathrm{~m}\end{array}$ & 31.7 & $\begin{array}{l}1.64 \\
1.94\end{array}$ \\
\hline 4 & 49.2 & & 49.0 & \\
\hline 5 & 76.6 & & 76.4 & \\
\hline 6 & 28.2 & $\begin{array}{l}1.84, \mathrm{ddd}(14.9,4.2,2.6) \\
2.37, \mathrm{td}(14.6,4.8)\end{array}$ & 27.9 & $\begin{array}{l}1.88, \mathrm{~m} \\
2.40, \mathrm{~m}\end{array}$ \\
\hline 7 & 21.8 & $\begin{array}{l}1.55, \mathrm{~m} \\
2.24, \mathrm{~m}\end{array}$ & 21.5 & $\begin{array}{l}1.60, \mathrm{~m} \\
2.33, \mathrm{~m}\end{array}$ \\
\hline 8 & 44.3 & $2.31, \mathrm{td}(11.9,4.8)$ & 44.2 & $2.33, \mathrm{~m}$ \\
\hline 9 & 44.7 & $2.59, \mathrm{~m}$ & 44.5 & $2.62, \mathrm{~m}$ \\
\hline 10 & 41.9 & & 41.7 & \\
\hline 11 & 23.4 & $\begin{array}{l}2.61, \mathrm{~m} \\
2.80, \mathrm{~m}\end{array}$ & 23.2 & $2.81, \mathrm{~m}$ \\
\hline 12 & 167.1 & & 166.8 & \\
\hline 13 & 119.8 & & 119.8 & \\
\hline 14 & 195.9 & & 196.1 & \\
\hline 15 & 106.4 & $6.59, \mathrm{dd}(2.0,0.4)$ & 106.5 & $6.64, d(2.0)$ \\
\hline 16 & 143.1 & 7.32, d (1.8) & 142.2 & 7.30, d (2.0) \\
\hline 17 & - & & - & \\
\hline 18 & 23.7 & $1.15, \mathrm{~s}$ & 23.7 & $1.19, \mathrm{~s}$ \\
\hline 19 & 177.2 & & 177.2 & \\
\hline 20 & 15.1 & 0.87, d (0.6) & 15.1 & $0.89, \mathrm{~s}$ \\
\hline 19-OMe & 51.7 & $3.65, \mathrm{~s}$ & 51.7 & $3.69, \mathrm{~s}$ \\
\hline
\end{tabular}

Assignments were based on COSY, HSQC and HMBC experiments 
against chloroquine-resistant $P$. falciparum Dd2 strains. The results showed that all extracts were active with $\mathrm{IC}_{50}<25 \mu \mathrm{g} / \mathrm{mL}$. Among the extracts investigated, root extracts of E. schliebenii and $H$. pubescens possessed the highest antiplasmodial activity with $\mathrm{IC}_{50}<5 \mu \mathrm{g} / \mathrm{mL}$. The ethanolic root extract of $E$. schliebenii had an $\mathrm{IC}_{50}$ of $1.87 \mu \mathrm{g} / \mathrm{mL}$ while methanolic and ethanolic root extracts of $H$. pubescens exhibited an $\mathrm{IC}_{50}=2.05 \mu \mathrm{g} / \mathrm{mL}$ and $\mathrm{IC}_{50}=2.43 \mu \mathrm{g} / \mathrm{mL}$, respectively. The aqueous extract of $E$. schliebenii stem bark $\left(\mathrm{IC}_{50}=7.04 \mu \mathrm{g} / \mathrm{mL}\right)$ and ethanolic extract of $D$. melleri $\left(\mathrm{IC}_{50}=8.23 \mu \mathrm{g} / \mathrm{mL}\right)$ demonstrated promising antiplasmodial activity while dichloromethane root extract of $C$. bonducella exhibited moderate antiplasmodial activity with $\mathrm{IC}_{50}$ of $24.05 \mu \mathrm{g} / \mathrm{mL}$ (Table 2). In addition, results of cytotoxicity study revealed that all extracts were non-toxic to mammalian (LLC-MK2) cells with $\mathrm{CC}_{50}>30 \mu \mathrm{g} / \mathrm{mL}$ cut-off point (Table 2 ).

Two fractions from the methanolic root extract of H. pubescens coded as HPRM-5 and 7 were evaluated for antiplasmodial activity against chloroquinesensitive $P$. falciparum (3D7), chloroquine-resistant (K1) and artemisinin-resistant strains (IPC 5202 Battambang and IPC 4912 Mondolkiri). Although the results revealed both fractions were active, HPRM-7 had high activity against all P. falciparum strains tested. Fraction HPRM-5 obtained from $40 \%$ ethyl acetate/petroleum ether column fractions inhibited the growth of $P$. falciparum 3D7 $\left(\mathrm{IC}_{50}=3.14 \mu \mathrm{g} / \mathrm{mL}\right), \mathrm{K} 1\left(\mathrm{IC}_{50}=5.23 \mu \mathrm{g} / \mathrm{mL}\right), \mathrm{IPC} 5202$ Battambang $\left(\mathrm{IC}_{50}=11.46 \mu \mathrm{g} / \mathrm{mL}\right)$ and IPC 4912 Mondolkiri $\left(\mathrm{IC}_{50}=8.61 \mu \mathrm{g} / \mathrm{mL}\right)$. Similarly, fraction HPRM-7 from $70 \%$ ethyl acetate/petroleum ether column fractions exhibited strong antiplasmodial activity against $3 \mathrm{D} 7$ with $\mathrm{IC}_{50}=1.2 \mu \mathrm{g} / \mathrm{mL}, \mathrm{K} 1\left(\mathrm{IC}_{50}=2.18 \mu \mathrm{g} / \mathrm{mL}\right)$, and IPC 5202 Battambang $\mathrm{IC}_{50}=2.52 \mu \mathrm{g} / \mathrm{mL}$ ) and promising activity against IPC 4912 Mondolkiri with $\mathrm{IC}_{50}=5.95 \mu \mathrm{g} / \mathrm{mL}$ (Table 3).

The 1:1 dichloromethane/ethyl acetate column fraction and its sub-fraction (sub-fraction 1) from dichloromethane crude extract of $C$. bonducella root exhibited high to moderate antiplasmodial activity against $P$. falciparum 3D7, P. falciparum Dd2 and P. falciparum IPC 4912 Mondolkiri. Generally, the activity of these fractions increased with purity of the fraction (Table 4). Norcaesalpin D isolated from sub-fraction 1 was active with $\mathrm{IC}_{50}$ of $0.98,1.85$ and $2.13 \mu \mathrm{g} / \mathrm{mL}$ against chloroquine-sensitive (3D7), chloroquine-resistant (Dd2) and artemisinin-resistant (IPC 4912 Mondolkiri) P. falciparum parasites, respectively. Cytotoxicity evaluation showed that norcaesalpin D is non-toxic to mammalian cells with $\mathrm{CC}_{50}>200 \mu \mathrm{g} / \mathrm{mL}$ (Table 4).

\section{Discussion}

This study aimed to assess the antiplasmodial activity of extracts of E. schliebenii roots and stem bark, H. pubescens roots, D. melleri aerial parts and C. bonducella roots. Also, the study assessed the antiplasmodial activity of fractions and norcaesalpin D isolated from $C$. bonducella roots.

The results indicate that extracts, fractions and norcaesalpin D possess in vitro antiplasmodial activity against chloroquine-sensitive (3D7), chloroquine-resistant (Dd2 and K1) and artemisinin-resistant P. falciparum (IPC 5202 Battambang and IPC 4912 Mondolkiri) parasites. According to Jonville et al., [22], antiplasmodial activity of extracts and fractions can be classified as high activity $\left(\mathrm{IC}_{50}<5 \mu \mathrm{g} / \mathrm{mL}\right)$, promising activity $\left(\mathrm{IC}_{50}=5-15 \mu \mathrm{g} / \mathrm{mL}\right)$, moderate activity $\left(\mathrm{IC}_{50}=15-50 \mu \mathrm{g} / \mathrm{mL}\right)$ and inactive $\left(\mathrm{IC}_{50}=>50 \mu \mathrm{g} / \mathrm{mL}\right)$. Based on this, all crude extracts of E. schliebenii, $H$. pubescens, D. melleri and $C$. bonducella were active against chloroquine-resistant P. falciparum Dd2; however, root extracts of E. schliebenii and $H$. pubescens exhibited the highest antiplasmodial activity with $\mathrm{IC}_{50}<5 \mu \mathrm{g} / \mathrm{mL}$. The aqueous extract of E. schliebenii stem bark, ethanolic extract of D. melleri, and dichloromethane root extract of $C$. bonducella showed promising to moderate antiplasmodial activity with $\mathrm{IC}_{50}<25 \mu \mathrm{g} / \mathrm{mL}$ (Table 2 ). In addition, cytotoxicity study of the extracts revealed that all extracts were non-toxic to mammalian (LLC-MK2) cells with

Table $\mathbf{2}$ In vitro anti-plasmodial activity and cytotoxicity of plant extracts

\begin{tabular}{|c|c|c|c|c|}
\hline \multirow[t]{2}{*}{ Plant (Family) } & \multirow[t]{2}{*}{ Part (extract) } & \multirow{2}{*}{$\begin{array}{l}\text { Antiplasmodial activity } \\
\mathrm{IC}_{50} \text { on } \mathrm{Dd} 2 \\
(\mu \mathrm{g} / \mathrm{mL} \pm \mathrm{SD})\end{array}$} & Cytotoxicity & \multirow{2}{*}{$\begin{array}{l}\text { Selectivity } \\
\text { index (SI) }\end{array}$} \\
\hline & & & $\mathrm{CC}_{50}$ on LLC-MK2 $(\mu \mathrm{g} / \mathrm{mL} \pm \mathrm{SD})$ & \\
\hline \multirow[t]{2}{*}{ Erythrina schliebenii (Fabaceae) } & R (80\% Ethanol) & $1.87 \pm 0.44$ & $>200$ & $>109$ \\
\hline & $\mathrm{SB}\left(\mathrm{H}_{2} \mathrm{O}\right)$ & $7.04 \pm 0.72$ & $>200$ & $>28.4$ \\
\hline \multirow[t]{2}{*}{ Holarrhena pubescens (Apocynaceae) } & R (80\% Ethanol) & $2.43 \pm 0.15$ & $>200$ & $>82.3$ \\
\hline & R (Methanol) & $2.05 \pm 0.56$ & $>200$ & $>97.6$ \\
\hline Dissotis melleri Hook.f (Melastomataceae) & AP (80\% Ethanol) & $8.23 \pm 1.32$ & $83.33 \pm 3.31$ & 10.1 \\
\hline Caesalpinia bonducella (Caesalpinaceae) & R (Dichloromethane) & 24.05 & $>200$ & $>8.3$ \\
\hline QN & & $0.06 \pm 0.01$ & & \\
\hline Gleevec ${ }^{\circ}$ (Imatinib) & & & $19.43 \pm 2.87$ & \\
\hline
\end{tabular}

$R$ root, $S B$ stem bark, $A P$ aerial parts (stem + leaves), $Q N$ quinine 
Table 3 In vitro antiplasmodial activity of fractions from $\mathrm{H}$. pubescens methanolic root extract

\begin{tabular}{|c|c|c|c|c|c|}
\hline \multirow[t]{2}{*}{ Fraction } & \multicolumn{4}{|c|}{$\begin{array}{l}\text { Antiplasmodial activity } \\
\mathrm{I}_{50} \pm \mathrm{SD}(\mu \mathrm{g} / \mathrm{mL})\end{array}$} & \multirow{2}{*}{$\begin{array}{l}\text { Cytotoxicity } \\
\text { CC } C_{50} \pm \text { SD }(\mu \mathrm{g} / \mathrm{mL} \\
\text { LLC-MK2 cells }\end{array}$} \\
\hline & $3 \mathrm{D7}$ & K1 & $\begin{array}{l}\text { IPC } 5202 \text { Battambang- } \\
\text { Cambodia } 2011\end{array}$ & $\begin{array}{l}\text { IPC } 4912 \text { Mondolkiri- } \\
\text { Cambodia } 2011\end{array}$ & \\
\hline Fraction HPRM- 5 & $3.14 \pm 0.18$ & $5.23 \pm 0.03$ & $11.46 \pm 0.2$ & $8.61 \pm 0.97$ & $>200$ \\
\hline Fraction HPRM- 7 & $1.20 \pm 0.35$ & $2.18 \pm 0.95$ & $2.52 \pm 1.8$ & $5.95 \pm 2.79$ & $>200$ \\
\hline QN & $0.052 \pm 0.01$ & $0.060 \pm 0.01$ & $0.074 \pm 0.0$ & $0.068 \pm 0.005$ & $>200$ \\
\hline
\end{tabular}

HPRM-5 40\% ethyl acetate/petroleum ether column fraction of $H$. pubescens methanolic root extract, HPRM-7 70\% ethyl acetate/petroleum ether column fraction of $H$. pubescens methanolic root extract, $Q N$ quinine

$\mathrm{CC}_{50}>80 \mu \mathrm{g} / \mathrm{mL}$ (Table 2). These findings against chloroquine-resistant $P$. falciparum parasites suggest that E. schliebenii, H. pubescens, D. melleri and C. bonducella can be potential sources for the isolation of safe and effective antimalarial lead compounds.

In our previous study we reported that extracts of $E$. schliebenii stem bark, $H$. pubescens roots and C. bonducella roots had in vivo antimalarial activity against $P$. berghei ANKA in mice [15]. In this study we found that extracts and fractions of these plants exhibited strong to moderate antiplasmodial activity against multi-drug resistant $P$. falciparum Dd2 malaria parasites. These findings therefore provide more scientific evidence on the antimalarial properties and the use of these plants in traditional medicines for the treatment of malaria. Furthermore, two column fractions from the active extract of $H$. pubescens roots showed high antiplasmodial activity against 3D7, K1, IPC 5202 Battambang and IPC 4912 Mondolkiri parasites. Fraction HPRM-7 from 70\% ethyl acetate/petroleum ether column fractions exhibited strong antiplasmodial activity against $3 \mathrm{D} 7\left(\mathrm{IC}_{50}=1.2 \mu \mathrm{g} / \mathrm{mL}\right), \mathrm{K} 1$ $\left(\mathrm{IC}_{50}=2.18 \mu \mathrm{g} / \mathrm{mL}\right)$, and IPC 5202 Battambang $\mathrm{IC}_{50}=2.52 \mu \mathrm{g} / \mathrm{mL}$ ) and promising activity against IPC 4912 Mondolkiri $\left(\mathrm{IC}_{50}=5.95 \mu \mathrm{g} / \mathrm{mL}\right)$ as presented in Table 3. Artemisinin-based combination therapies (ACTs) are currently the only effective drugs available for the treatment of malaria [23]. However, recent report on the emergence of $P$. falciparum parasites resistant to dihydroartemisinin-piperaquine [10] which is one of the highly effective ACTs is an indication that new molecules with antimalarial properties need to be discovered. The antiplasmodial activity observed in some of the extracts and fractions against artemisinin-resistant $P$. falciparum suggest that medicinal plants can still offer more antimalarial lead compounds for future drug development.

While the antiplasmodial properties of extracts of $E$. schliebenii, $H$. pubescens and $C$. bonducella were reported earlier $[13,14,24]$, the antiplasmodial activity of D. melleri is reported for the first time by this study. Ethanolic extract of $D$. melleri aerial parts showed promising antiplasmodial activity against $P$. falciparum $\mathrm{Dd} 2$ parasites in vitro with $\mathrm{IC}_{50}=8.23 \mu \mathrm{g} / \mathrm{mL}$. A previous study showed that stem extracts of Dissotis brazzae Cogn exhibited antiplasmodial activity against $P$. falciparum chloroquine-resistant (ENT 36 strain) with $\mathrm{IC}_{50}=6.4 \mu \mathrm{g} / \mathrm{mL}$. Preliminary phytochemical analysis of the extracts of $D$. brazzae revealed the presence of alkaloids, coumarins, saponins, triterpenoids, steroids, and tannins which are associated with the antiplasmodial activity of this plant [25]. The antiplasmodial activity of $D$. melleri could therefore be an indication that the genus Dissotis can be a potential source for the isolation of compounds with antimalarial activity.

Dichloromethane crude extract of $C$. bonducella root was reported earlier to have dose-dependent in vivo antimalarial activity in mice [15]. The results from this study indicate that dichloromethane crude extract of $C$. bonducella root exhibited low in vitro antiplasmodial activity (Table 2). The low in vitro antiplasmodial activity observed in this study can be explained by the poor solubility of the extracts in aqueous medium. This extract dissolved completely in dimethylsulfoxide but

Table 4 Anti-plasmodial activity of Norcaesalpin D and fractions from C. bonducella roots

\begin{tabular}{|c|c|c|c|c|c|}
\hline \multirow[t]{2}{*}{ Fraction/Compound } & \multicolumn{3}{|c|}{$\begin{array}{l}\text { Antiplasmodial activity } \\
\mathrm{I}_{50} \pm \mathrm{SD}(\mu \mathrm{g} / \mathrm{mL})\end{array}$} & \multirow{2}{*}{$\begin{array}{l}\text { Cytotoxicity } \mathrm{CC}_{50} \pm \mathrm{SD}(\mu \mathrm{g} / \mathrm{mL}) \\
\mathrm{CC}_{50} \text { on LLC-MK2 }(\mu \mathrm{g} / \mathrm{mL} \pm \mathrm{SD})\end{array}$} & \multirow[t]{2}{*}{$\begin{array}{l}\text { Selectivity index } \\
\text { (SI) against IPC-4912 }\end{array}$} \\
\hline & $3 \mathrm{D} 7$ & $\mathrm{Dd} 2$ & IPC 4912 Mondolkiri Cambodia 2011 & & \\
\hline 1:1 DCM/EtoAC fraction & $4.08 \pm 2.87$ & $9.33 \pm 2.09$ & $2.99 \pm 4.84$ & $76.09 \pm 8.44$ & 25.4 \\
\hline Sub-fraction 1 (Semi-pure) & $3.06 \pm 0.80$ & $2.26 \pm 0.97$ & $5.12 \pm 1.0$ & $>200$ & $>39.1$ \\
\hline Norcaesalpin D compound & $\begin{array}{l}0.98 \pm 0.03 \\
(2.83 \mu \mathrm{M})\end{array}$ & $\begin{array}{l}1.85 \pm 0.05 \\
(5.35 \mu \mathrm{M})\end{array}$ & $\begin{array}{l}2.13 \pm 0.7 \\
(6.16 \mu \mathrm{M})\end{array}$ & $\begin{array}{l}>200 \\
(>578 \mu \mathrm{M})\end{array}$ & $>93.9$ \\
\hline QN & $0.052 \pm 0.01$ & $0.06 \pm 0.01$ & $0.068 \pm 0.005$ & & \\
\hline
\end{tabular}

1:1 DCM/EtoAC =1:1 dichloromethane/ethyl acetate fraction of dichloromethane root extract of $C$. bonducella; Sub-fraction 1 = column fraction of 1:1 DCM/EtoAC fraction; Norcaesalpin D isolated from sub-fraction1 
precipitated on addition of aqueous solvents. However, dichloromethane/ethyl acetate (1:1) column fraction and its sub-fraction 1 from dichloromethane root extract of $C$. bonducella showed high in vitro antiplasmodial activity against $P$. falciparum 3D7, Dd2 and IPC 4912 Mondolkiri strains (Table 4). Norcaesalpin D (Fig. 1) is a 17norcassane furanoditerpene isolated from the subfraction 1. This compound revealed strong antiplasmodial activity with $\mathrm{IC}_{50}$ of $0.98,1.85$ and $2.13 \mu \mathrm{g} / \mathrm{mL}$ against P. falciparum 3D7, Dd2 and IPC 4912 Mondolkiri parasites, respectively (Table 4). The antiplasmodial activity of this compound is reported for the first time by this study. A previous study indicated that this compound together with 17-O-Demethylbonducellpin C; 7-Dehydr oxycaesaldekarin I; Caesaldekarin C, Caesaldekarin F, Caesaldekarin $\mathrm{J}$ and Caesalpin $\mathrm{F}$ were isolated from dichloromethane root extract of C. bonducella but no antiplasmodial activity was reported. Caesaldekarin $\mathrm{C}$ and Caesaldekarin $\mathrm{F}$ were reported to have cytotoxic activity against a number of cancer cell lines [21]. In addition, cassane-type diterpenoid compounds from Caesalpinia have been reported to have antiplasmodial properties. Norcaesalpinin E from the seeds of C. crista revealed high antiplasmodial activity $\left(\mathrm{IC}_{50}=0.09 \mu \mathrm{M}\right)$ against $P$. falciparum FCR - 3/A2 [26]. Thus, the in vitro antiplasmodial activity of norcaesalpin D observed in this study confirms the antimalarial activity of the C. bonducella root extract. Further evaluation of the compound for in vivo antimalarial activity is suggested.

\section{Conclusions}

Antiplasmodial activity of the extracts of E. schliebenii, H. pubescens, D. melleri and C. bonducella reported in this study provide scientific evidence supporting their use for the treatment of malaria. Antiplasmodial activity demonstrated by norcaesalpin $\mathrm{D}$ against artemisininresistant $P$. falciparum parasites requires further attention for the discovery of antimalarial lead compounds for future use.

\footnotetext{
Abbreviations

${ }^{13}$ C-NMR: Carbon-13 nuclear magnetic resonance; ${ }^{1} \mathrm{H}-\mathrm{NMR}$ : Proton nuclear magnetic resonance; COSY: Correlation spectroscopy; El-MS: Electron ionization mass spectroscopy; HMBC: Heteronuclear multiple bond correlation; HSQC: Heteronuclear single quantum correlation; MS: Mass spectroscopy; NMR: Nuclear magnetic resonance; NOESY: Nuclear overhauser effect spectroscopy; WHO: World Health Organization
}

\section{Acknowledgements}

Authors are very grateful to Sida for the financial support. We would like to acknowledge Mr. Haji. O. Selemani (Botanist) for scientific identification of the medicinal plants used in this study. Extraction, fractionation and isolation of the compound were done at the Institute of Traditional Medicine (MUHAS-Tanzania) while in vitro antiplasmodial and cytotoxicity assays were conducted at the University of Buea in Cameroon. Spectral analysis was done at the University of Potsdam (Universität Potsdam, Institut für Chemie) in Germany.

\section{Funding}

This research work was financially supported by the Swedish International Development Cooperation Agency (Sida) through Muhimbili University of Health and Allied Sciences.

\section{Availability of data and materials}

All data that support the conclusions of this study are included in this article.

\section{Authors' contribution}

RSON participated in study concept and design, data acquisition, data analysis, and drafting the manuscript. MJM, DZ and PE were involved in study concept, study design and revising the manuscript. AWK, PJM, FM and $\mathrm{MH}$ participated in data acquisition, data analysis and revising the manuscript. All authors read and approved the final manuscript for publication.

\section{Competing interests}

The authors declare that they have no competing interests.

Consent for publication

Not applicable.

Ethics approval and consent to participate Not applicable.

\section{Author details}

${ }^{1}$ Department of Biological and Pre-Clinical Studies, Institute of Traditional Medicine, Muhimbili University of Health and Allied Sciences, P.O.Box 65001, Dar es Salaam, Tanzania. ${ }^{2}$ National Institute for Medical Research, P.O.Box 9653, Dar es Salaam, Tanzania. ${ }^{3}$ Department of Natural Products Development and Formulation, Institute of Traditional Medicine, Muhimbili University of Health and Allied Sciences, P.O.Box 65001, Dar es Salaam, Tanzania. ${ }^{4}$ Institut für Chemie, Universität Potsdam, Karl-Liebknecht, Str. 24-25, 14476, Golm, Germany. ${ }^{5}$ Biotechnology Unit, University of Buea, P.O.Box 63, BueaSouth West RegionCameroon.

Received: 9 July 2016 Accepted: 8 March 2017

Published online: 24 March 2017

\section{References}

1. WHO. WHO Global Malaria Programme: World Malaria Report. Geneva: World Health Organization; 2014. p. 2014.

2. WHO. World Malaria Report 2015. Geneva: World Health Organization; 2015.

3. WHO. WHO Global Malaria Programme: World Malaria Report 2012. Geneva: World Health Organization; 2012.

4. Dondorp AM, Fairhurst RM, Slutsker L, MacArthur JR, Breman JG, Guerin PJ, Wellems TE, Ringwald P, Newman RD, Plowe CV. The threat of artemisininresistant malaria. N Engl J Med. 2011;365(12):1073-5.

5. Fernández-Álvaro E, Hong WD, Nixon GL, O’Neill PM, Calderón F. Antimalarial chemotherapy: Natural product inspired development of preclinical and clinical candidates with diverse mechanisms of action. J Med Chem. 2016;59(12):5587-603.

6. Wongsrichanalai C, Pickard AL, Wernsdorfer WH, Meshnick SR. Review: Epidemiology of drug-resistant malaria. Lancet Infect Dis. 2002;2(4):209-18.

7. Faurant C. From back to Weed: The history of artemisinin. Parasite. 2011; 18(3):215-8

8. Hay SI, Guerra CA, Tatem AJ, Noor AM, Snow RW. The global distribution and population and population at risk of malaria: past, present, and future. Lancet Infect Dis. 2004;4(6):327-36.

9. WHO. WHO Global Malaria Programme: Status report on artemisinin resistance. Geneva: World Health Organization; 2014. [http://www.who.int/ malaria/publications/atoz/status_rep_artemisinin_resistance_jan2014. pdf?ua=1]. Accessed June 2016.

10. Amarutanga C, Lim P, Suon S, Sreng S, Mao S, Sopha B, Sam B, Dek D, Try V, Amato R, Blessborn D, Song L, Tullo GS, Fay MP, Anderson JM, Tarning J, Fairhurst RM. Dihydroartemisinin-piperaquine resistance in Plasmodium falciparum malaria in Cambodia. A multisite prospective cohort study. Lancet Infect Dis. 2016;16(3):357-65.

11. Aguiar ACC, da Roche EMM, de Souza NB, França TCC, Krettli AU. New approaches in antimalarial drug discovery and development- A review. Mem inst Oswaldo Cruz, Rio de Janeiro. 2012;107(7):831-45. 
12. Innocent E, Moshi MJ, Masimba PJ, Mbwambo ZH, Kapingu MC. Screening of traditionally used plants for in vivo antimalarial activity in mice. Afr J Tradit Complement Altern Med. 2009;6(2):163-7.

13. Nondo RSO, Zofou D, Moshi MJ, Erasto P, Wanji S, Ngemenya MN, Titanji VPK, Kidukuli AW, Masimba PJ. Ethnobotanical survey and in vitro antiplasmodial activity of medicinal plants used to treat malaria in Kagera and Lindi regions Tanzania. J Med Plants Res. 2015;9(6):179-92.

14. Sigh V, Raghav P. Review on pharmacological properties of Caesalpinia bonduc L. Int J Med Arom Plants. 2012;2(3):514-30.

15. Nondo RSO, Erasto P, Moshi MJ, Zacharia A, Masimba PJ, Kidukuli AW. In vivo antimalarial activity of extracts of Tanzanian medicinal plants used for the treatment of malaria. J Adv Pharm Technol Res. 2016;7(2):59-63.

16. Jermain JD, Evans HK. Analyzing Salvia divinorum and its active ingredient Salvinorin A utilizing thin layer chromatography and gas chromatography/ mass spectrometry. J Forensic Sci. 2009:54(3):612-6.

17. Trager $\mathbf{W}$, Jensen JB. Human malaria parasites in continuous culture. Science. 1976;193(4254):673-5.

18. Makler MT, Hinrichs DJ. Measurement of the lactate dehydrogenase activity of Plasmodium falciparum as an assessment of parasitaemia. Am J Trop Med Hyg. 1993:48(2):205-10.

19. Zofou D, Kengne ABO, Tene M, Ngemenya MN, Tane P, Titanji VPK. In vitro antiplasmodial activity and cytotoxicity of crude extracts and compounds from the stem bark of Kigelia africana (Lam.) Benth (Bignoniaceae). Parasitol Res. 2011;108(6):1383-90.

20. Nondo RSO, Moshi MJ, Erasto P, Zofou D, Njouendou AJ, Wanji S, Ngemenya MN, Kidukuli AW, Masimba PJ, Titanji VPK. Evaluation of the cytotoxic activity of extracts from medicinal plants used for the treatment of malaria in Kagera and Lindi regions, Tanzania. J App Pharm Sci. 2015;5(4):007-12

21. Roach JS, McLean S, Reynolds WF, Tinto WF. Cassane and norcassane diterpenoids of Caesalpinia bonduc. Heterocycles. 2007;71(5):1067-73.

22. Jonville MC, Kodja H, Humeau L, Fournel J, De mol P, Cao M, Angenot L, Frédérich M. Screening of medicinal plants from Reunion Island for antimalarial and cytotoxic activity. J Ethnopharmacol. 2008;120(3):382-6.

23. WHO. WHO Global Malaria Programme: Guidelines for the treatment of malaria. 3rd edtition ed. Geneva: World Health Organization; 2015.

24. Simonsen HT, Nordskjold JB, Smitt UW, Nyman U, Palpu P, Joshi P, Varughese $\mathrm{G}$. In vitro screening of Indian medicinal plants for antiplasmodial activity. J Ethnopharmacol. 2001;74(2):195-204.

25. Omulokoli E, Khan B, Chhabra SC. Antiplasmodial activity of four Kenyan medicinal plants. J Ethnopharmacol. 1997;56(2):133-7.

26. Linn TZ, Awale S, Tezuka Y, Banskota AH, Kalauni SK, Attamimi F, Ueda JY, Asih PB, Syafruddin D, Tanaka K, Kadota S. Cassane- and norcassane-type diterpenes from Caesalpinia crista of Indonesia and their antimalarial activity against the growth of Plasmodium falciparum. J Nat Prod. 2005;68(5):706-10.

\section{Submit your next manuscript to BioMed Central and we will help you at every step:}

- We accept pre-submission inquiries

- Our selector tool helps you to find the most relevant journal

- We provide round the clock customer support

- Convenient online submission

- Thorough peer review

- Inclusion in PubMed and all major indexing services

- Maximum visibility for your research

Submit your manuscript at www.biomedcentral.com/submit

) Biomed Central 